\title{
Riglyne vir die implementering van 'n eienaar-drywerstelsel
}

\author{
J.S. Spamer \& W.J. Pienaar* \\ Departement Vervoerekonomie \& Logistiek, Universiteit van Stellenbosch, Privaatsak X1, Matieland \\ 7602 Republiek van Suid-Afrika \\ mmt@maties.sun.ac.za
}

\begin{abstract}
Guidelines for the implementation of an owner-driver scheme. The aim of this article is to supply guidelines for the implementation of an owner-driver scheme. Such implementation is the outsourcing of a firm's transport obligations to vehicle owner-drivers who are not employees of the firm. In most cases these individuals are ex-employees of the firm who are now acting as independent hauliers. The objectives of an owner-driver scheme and the different forms which such a scheme can adopt, are briefly outlined. Thereafter the criteria for implementation, and also the critical success factors of such a scheme. are discussed. It is pointed out that the firm will have to decide whose responsibility it is to initially manage the scheme. This decision, combined with the contract, the method of financing and the renumeration system, determine the nature of an owner-driver scheme. Firms wishing to implement an owner-driver scheme should approach it in a structured manner within a well-considered implementation programme. Implementation of the owner-driver scheme is discussed according to six phases, namely: (1) initiation, (2) evaluation, (3) planning, (4) contracting, (5) transition, and (6) management and review.
\end{abstract}

\begin{abstract}
Die doel van die artikel is om riglyne daar te stel vir die implementering van 'n eienaar-drywerstelsel. Die implementering van so 'n stelsel is die uitkontraktering van 'n onderneming se vervoerverpligtinge aan voertuigeienaar-drywers wat nie in diens van die onderneming is nie. In die meeste gevalle is hierdie individue vorige werknemers van die onderneming, wat nou as onafhanklike karweiers optree. Die doelstellings van, en die onderskeie vorme wat 'n eienaar-drywerstelsel kan aanneem. word kortliks in die artikel toegelig. Daarna word die kriteria vir implementering, en die kritieke suksesfaktore vir so in steisel bespreek. As vertrekpunt word aangetoon dat die onderneming moet besluit wie die verantwoordelikheid van die bestuur en administrasie van die stelsel gaan behartig. Hierdie besluit, tesame met die kontrak, die metode van finansiering. en die vergoedingstelsel bepaal die aard van 'n eienaar-drywerstelsel. Ondernemings wat 'n eienaardr?werstelsel in bedryf wil stel, moet dit op 'n gestruktureerde wyse volgens ' $n$ weldeurdagte implementeringsprogram uitv oer. Implementering van die eienaar-drywerstelsel word aan die hand van ses fases bespreek, naamlik: (1) aanvang, (2) evaluering, (3) beplanning, (4) kontraktering, (5) oorgang, en (6) bestuur en hersiening.
\end{abstract}

*Skrywer aan wie korrespondensie gerig moet word.

\section{Inleiding}

Verskeie Suid-Afrikaanse ondernemings het in die laaste aantal jare begin om eienaar-drywerstelsels te implementeer. Ofskoon die implementering van 'n eienaar-drywerstelsel 'n strategie is om die langtermynwinsgewendheid van 'n onderneming te verhoog, word dit in Suid-Afrika ook as instrument gebruik vir die bemagtiging van werkers. Hierdie vorm van uitkontraktering hou egter bepaalde risiko's in wat deeglik deur al die betrokke partye in ag geneem moet word. Ondernemings wat so 'n stelsel wil implementeer, moet hulle besluit volgens duidelike doekwitte en kriteria kan regverdig. Implementering moet daarom weldeurdag en goed gestruktureerd geskied. Daar moet duidelikheid wees oor die redes vir implementering, asook wat die onderskeie voor- en nadele van die stelsel is.

Veranderinge aan 'n onderneming se bestaande vervoer- en distribusiestelsel kan ' $n$ ingewikkelde en langsame proses wees wat oor die lang termyn tot nadeel van al die betrokke partye strek. Hoewel ondernemings gedwing word om by hulle omgewing aan te pas, moet verandering op 'n geordende wyse plaasvind en bestuur word om risiko's te beperk.

Die meeste ondernemings beweeg eers deur 'n leerproses, voordat hulle onderskeie stelsels vlot bedryf word. Tydens implementering word daar gewoonlik verskeie taktiese probleme ondervind wat die doeltreffendheid en koste-doelmatigheid van die stelsel kan ondermyn. Daarom bestaan daar 'n behoefte aan bestuursriglyne waarvolgens ' $n$ eienaar-drywerstelsel in bedryf gestel kan word.

\section{Metode van ondersoek}

Die riglyne wat in hierdie artikel verskaf word, is 'n sintese gegrond op ingesamelde inligting. Inligting is verkry uit interne dokumente van twaalf ondernemings, die bedryfskontrakte van vier ondernemings, 15 persoonlike onderhoude met ondernemingsbestuurders wat gemoeid is met eienaar-drywerstelsels, en 46 voltooide vraelyste.

Twee tipes vraelyste is gebruik, een gerig aan bestuurslede van die onderneming, en een wat aan die eienaar-drywer gerig is. Die doel van die vraelyste was tweeledig, naamlik:

- Om ' $n$ beter begrip van die aard en werking van die onderskeie eienaar-drywerstelsels te verkry wat saam met die ander inligtingsbronne verwerk kan word; en

- Om as 'n kontrolelys of opsomming te dien van kriteria wat in ag geneem moet word waar die implementering van 'n eienaar-drywerstelsel oorweeg word.

Bogenoemde opnames is aangevul met ' $n$ literatuurstudie. Enersyds is kommersiële vervoergerigte tydskrifte gefynkam vir wetenswaardighede rakende eienaar-drywerstelsels en andersyds is vakkundige artikels oor uitkontraktering, wat op eienaar-drywerstelsels van toepassing kan wees, geraadpleeg. 


\section{Eienaar-drywers teenoor eienaar-operateurs}

Die term eienaar-operateur word dikwels as 'n sinoniem vir die term eienaar-drywer gebruik. Alhoewel die eienaar-drywer volgens wetgewing as 'n operateur moet registreer (en inderdaad optree as die operateur van die voertuig), bestaan daar wel ' $n$ betekenisvolle begripsverskil tussen bogenoemde terme. Volgens die Nasionale Padverkeerswet (Suid-Afrika, 1996: Afdeling 74), is die eienaar van 'n motorvoertuig van 'n voorgeskrewe klas (vragmotors) die operateur van sodanige motorvoertuig, en moet as sodanig ingevolge hierdie afdeling van die wet registreer. Hierdie bepaling sluit ook persone in wat nie 'n drywer, werknemer, of agent van die eienaar van die motorvoertuig (vragmotor) is nie, maar 'n skriftelike ooreenkoms het dat die motorvoertuig deur sodanige persoon gebruik kan word vir 'n tydperk soos beskryf deur dié wet.

Die operateur is dus die eienaar van die voertuig, maar nie noodwendig die drywer van die voertuig nie. 'n Onderneming wat verantwoordelik is vir sy eie vervoer- en distribusieverpligtinge, en wat oor sy eie vloot vragmotors beskik, word dus ook as 'n operateur gesien, indien die onderneming eienaarskap oor die voertuie het. Donohue (1991: 58-59) maak melding van die afwesigheid van 'n standaard-definisie vir die beskrywing van 'n eienaar-drywer, maar verwys na 'n eienaar-drywer as ' $n$ padvragoperateur wat 'n enkele vragmotor huur, besig is om een aan te koop of reeds besit, en wat hoofsaaklik of uitsluitlik deur die eienaar bestuur word, behalwe tydens periodes van siekte of vakansie. 'n Onderskeid word gemaak tussen 'n eienaar-drywer en 'n eienaar-operateur deurdat 'n operateur een of meer vragmotors mag hê, waarvan die eienaar wel een van die vragmotors mag bestuur, maar nie bestuur waar slegs een vragmotor besit word nie.

Daar kan tussen twee tipes eienaar-drywers onderskei word, naamlik dié wat deel is van 'n eienaar-drywerstelsel, en dié wat op die ope mark as vragsoekers meeding, en dikwels met behulp van vervoermakelaars vragte bekom om te karwei. Hoewel laasgenoemde groep ook kontrakwerk kan doen, vorm hulle nie werklik deel van 'n eienaar-drywerstelsel nie. Eienaar-drywerstelsels wat in hierdie artikel onder bespreking is, vorm deel van ' $n$ bedeling waar ' $n$ formele kontrak tussen ' $n$ onderneming en eienaar-drywer of ' $n$ bestuursmaatskappy bestaan.

Drywers wat deel is van 'n eienaar-drywerstelsel kan met die nodige hulp en ondersteuning tot volwaardige operateurs ontwikkel wat hulle dienste nie net aan 'n spesifieke onderneming beskikbaar hoef te stel nie, maar ook in die ope mark kan meeding. Alhoewel eienaar-drywers as onafhanklike kontrakteurs beskou word, is hulle egter nog altyd aangewese op die onderneming se bystand.

In Suid-Afrika word die eienaar-drywerstelsel ook as 'n instrument vir die bemagtiging van nie-blanke werknemers gebruik waardeur hulle 'n geleentheid gebied word om hulle vaardighede as sakemanne te ontwikkel binne ' $n$ beskermde omgewing, wat nie volkome aan markkragte blootgestel is nie. Die bemagtigingsdoelwit van 'n eienaar-drywerstelsel behoort dus die volle oorgang in te sluit, wat ' $n$ bestuurde ontvoogdingsproses vanaf werknemer na eienaar-drywer na eienaar-operateur is. Dit beteken dat die eienaar-drywer aan die einde van sy kontrakperiode 'n volwaardige en ongebonde vervoeroperateur kan wees wat onafhanklik optree, en oor die potensiaal beskik om sy onderneming koste-doelmatig en doeltreffend te bestuur.

\section{Eienaar-drywerstelsel}

Die implementering van 'n eienaar-drywerstelsel is die uitkontraktering van 'n ondememing se vervoerverpligtinge aan individue. In die meeste gevalle is hierdie individue vorige werknemers van die onderneming wat nou as onafhanklike karweiers optree. Die onafhanklikheid van die karweier as ' $n$ eienaar-drywer word egter bepaal deur die tipe eienaardrywerstelsel met die besondere kontrakwaardes wat daarmee gepaard gaan.

'n Eienaar-drywerstelsel kan verskeie vorme aanneem om aan die onderneming se behoeftes te voldoen. Verder sal die aard daarvan ook verskil soos wat elke onderneming se bedrywighede verskil. Volgens Prodrive (1997: 2-6), 'n bestuurs- en ontwikkelingsmaatskappy vir beroepsdrywers, kan daar tussen drie wyses van inwerkingstelling van 'n eienaardrywerstelsel onderskei word. Hierdie wyses is (1) die ontwikkeling van 'n eie stelsel, (2) die oprig van 'n onafhanklike stelsel, en (3) 'n stelsel wat deur 'n bestuursmaatskappy bestuur word. Die drie wyses van ontwikkeling word vervolgens bespreek.

\section{Onderneming ontwikkel eie stelsel}

Die voordeel van hierdie stelsel is dat die onderneming volle beheer het. Daar is ook geen addisionele koste in die vorm van winsdeling of ' $n$ bestuursfooi nie. Hierteenoor moet die onderneming van voor af deur 'n leerproses gaan. Die tipe stelsel is onderhewig aan ingewikkelde kontraktuele ooreenkomste wat teen aansienlike koste en tydsverloop deur die onderneming opgestel moet word.

'n Eie stelsel benodig ondersteuningsdienste, veral administratiewe ondersteuning en bestuursinligting, wat van nuuts af geskep moet word. Die vordering van belasting op toegevoegde waarde (BTW) deur die owerheid plaas 'n bykomende las op die administrasie van die stelsel vir die onderneming. Die afwesigheid van 'n derde party veroorsaak dat daar geen buffer is tussen die onderneming en die vakbonde nie.

\section{Oprig van ' $n$ onafhanklike eienaar-drywerstelsel}

Volgens hierdie stelsel sal die bestuurs- en ontwikkelingsmaatskappy 'n onafhanklike eienaar-drywerstelsel vir sy eie rekening oprig. Sommige van die voertuie (vragmotors) word dan uitgeplaas na die spesifieke onderneming wat sy kliënt is. In wese ontstaan daar dus 'n vervoermaatskappy wat uit eienaar-drywers bestaan, maar bestuur word deur die bestuursen ontwikkelingsmaatskappy. Daar is dus geen band tussen die eienaar-drywer en die onderneming wat hy moet bedien nie.

\section{'n Bestuursmaatskappy bestuur die eienaar-drywerstel- sel}

Die stelsel word bestuur deur 'n derde party (bestuursmaatskappy) en dié ontvang ' $n$ bepaalde fooi daarvoor. Die bestuursmaatskappy neem die administratiewe funksies oor, en lewer 'n gespesialiseerde diens. Eienaar-drywers kan nou 
op hulle primère of hoof sakefunksie konsentreer as onafhanklike vervoerkontrakteurs, terwyl die bestuursmaatskappy hulle belange behartig.

Onafhanklike projekbestuurders met ondervinding is dikwels die beste toegerus om eienaar-drywerstelsels te ontwikkel en te bestuur (Nissan Diesel, 1996: 3). Dit is ook moontlik dat 'n derde party net betrokke kan wees by die ontwikkeling en/of inbedryfstelling van die stelsel. Daarna bedryf en bestuur die onderneming die stelsel alleen. Waar dit benodig word, kan die hulp van 'n derde party weer eens gebruik word. Ideaalgesproke behoort daar 'n langtermynverbintenis te wees tussen die eienaar-drywer, die onderneming, en 'n derde party wat of ' $n$ bestuursmaatskappy of ' $n$ ervare konsultant is.

\section{Kriteria vir implementering van 'n eienaar-drywer- stelsel}

Die eienaar-drywerstelsel kan net suksesvol wees indien al die betrokke partye daaruit voordeel trek. Dit is daarom raadsaam dat die onderneming die betrokke werknemers se vakbonde raadpleeg wanneer dit so 'n stelsel in bedryf wil stel. Die wyse van raadpleging sal, na gelang van die kultuur en vlak van arbeidsverhoudinge, tussen die onderskeie ondernemings verskil. Dit is 'n voorwaarde vir die sukses van 'n eienaar-drywerstelsel dat die betrokke werknemers oortuig moet wees van die onderneming se goeie trou en van die potensiële wedersydse voordeligheid daarvan. Bepaalde kriteria moet dus vasgestel word voordat die stelsel geïmplementeer kan word. Rypstra (1996: 38) identifiseer die volgende kriteria vir suksesvolle implementering:

- Duidelike doelwitte en strategieë moet neergelê wees om die stelsel te kan regverdig.

- Die eienaar-drywerkonsep en sy werking moet volgens sakebeginsels bestuur en aangepas word.

- Die keuringsproses moet omvattend wees sodat die regte persone gekies word om eienaar-drywers te word. Sekere stelsels vereis dat die drywer eers 'n proeftydperk moet voltooi voordat toelating tot die eienaar-drywerstelsel geskied.

- Omvattende opleiding moet deel wees van die implementeringsproses. Opleiding is veral van belang waar sekere nuwe vaardighede aangeleer. moet word. Die oorskakeling van werknemer na eienãar kan sodoende ook glad verloop. Volgens Chapman (1995: 60) bied sommige ondernemings hul eienaardrywers opleiding wat die volgende modules insluit: versekering, wetlike aspekte by die bestuur van ' $n$ onderneming, die padverkeerskwaliteitstelsel, boekhouding, kontantbestuur, besigheidsoriëntasie, voertuigonderhoud en kliëntesorg.

- Die eienaar-drywerskap moet aansporend en lonend wees vir die drywer. Daar moet voldoende vragvolume beskikbaar wees sodat die eienaar-drywer meer verdien namate meer vrag vervoer word. Waar seisoenale afplattings van die beskikbare volume plaasvind, moet daar by wyse van 'n vergoedingsmeganisme daarvoor voorsiening gemaak word.

- Die stelsel moet wedersyds vir die onderneming en die eienaar-drywer tot voordeel strek, en laasgenoemde volgens prestasie beloon.

- Daar moet sterk kommunikasiemeganismes wees om 'n oop verhouding en wedersydse vertroue tussen die partye te verseker

- Voortdurende besigheidsondersteuning vir die eienaardrywers is van groot belang. Om reg te laat geskied aan die stelsel moet daar 'n kwaliteitsbeheermeganisme wees.

Dit is belangrik dat die nodige ondersoeke, onderhande lings, en voorbereidings gedoen word voordat daar met die implementering van die stelsel begin word. Volgens Rypstra (1996: 38) moet ondernemings probeer om die volgende foute te vermy:

- Onvoldoende ontwikkeling van 'n loodsprojek. ('n Loodsprojek is onontbeerlik vir enige eienaar-drywerstelsel. Hiertydens kan potensiële probleme geïdentifiseer word.)

- Vinnige en onbeheerde geografiese uitbreiding.

- Onvoldoende eienaar-drywerkeuringsmeganisme.

- Onvoldoende inkomste vir beide partye in 'n onstabiele en onlonende mark.

Kritieke suksesfaktore vir 'n eienaar-drywerstelsel sal verskil volgens die onderneming se aktiwiteite. Die vernaamste faktore wat moontlik van toepassing sal wees, word in Tabel 1 getoon.

Die sukses van 'n eienaar-drywerstelsel is onderhewig aan bepaalde faktore wat vroegtydig deur ondernemings geïdentifiseer moet word. Hierdie faktore sal op die lang termyn bepaal of die onderneming se eienaar-drywerstelsel finansieel en operasioneel lewensvatbaar is.

\section{Aard van ' $n$ eienaar-drywerstelsel}

Die aard van 'n eienaar-drywerstelsel word deur verskeie faktore bepaal. ' $n$ Eienaar-drywerstelsel is 'n breë konsep wat vorm aanneem volgens die onderneming se aktiwiteite en

Tabel 1 Kritieke suksesfaktore vir eienaar-drywerstelsels

\begin{tabular}{ll}
\hline Faktore & Praktiese implikasies \\
\hline $\begin{array}{l}\text { 1. Handhawing van ooreenge- } \\
\text { kome afleweringstandaarde. }\end{array}$ & $\begin{array}{l}\text { Daar moet standaarde of riglyne wees } \\
\text { waarvolgens prestasie gemeet kan word. } \\
\text { Dit is veral van belang waar 'n spesificke } \\
\text { roete bedien word. }\end{array}$
\end{tabular}

2. Operasioneie aanpasbaarheid Fluktuasies in die volume affekteer die waar die verkoopsvolumes hoeveelheid werksure en mannekrag beverander. nodig, direk. Waar die produk seisoenaal van aard is, moet na alternatiewe produkte vir aflewering gekyk word

3. Die vermoe om aan te pas vol- Buigsame kliëntediens kan aan die ondergens die kliênt se behoeftes en neming ' $n$ mededingende voordeel gee. stelsels. Die eienaar-drywer moet dus aanpasbaa wees soos wat behoeftes verskil.

4. Handhawing van 'n kostedoel- Dit is noodsaaklik dat daar 'n doelmatige distribusiestruktuur treffende bestuursinligtingstelsel is. Die eienaar-drywer kan sodoende sy posisie monitor.

5. Die vermoe om interne fondse Die eienaar-drywer moet die voertuig me te genereer vir finansiering van verloop van tyd vervang. Daar moet hierdie bates (hoofsaaklik die afle- voor begroot word. Eienaar-drywers moet weringsvoertuig) dus voorsiening maak vir die nodige fondse, hetsy die vragmotor gekoop of gehuur is.

Die sukses van 'n eienaar-drywerstelsel is onderhewig aan bepaalde faktore wat vroegtydig deur ondernemings geïdentifiseer moet word. Hierdie faktore sal op die lang termyn bepaal of die onderneming se eienaar-drywerstelsel finansieel en operasioneel lewensvatbaar is 
behoeftes. Daar moet dus keuses gemaak word tussen 'n groot aantal veranderlikes. As vertrekpunt moet die onderneming besluit wie die verantwoordelikheid van die bestuur en administrasie van die stelsel gaan behartig. Dit is gewens dat die bestuur en administrasie deur middel van 'n spesiaal toegewyde administratiewe eenheid geskied. Die graad van verantwoordelikheid van dié eenheid moet duidelik in die kontrak tussen die betrokke partye beskryf word. Die kontrakte en bedryfshandleiding of diensvlakooreenkoms kan as die hartklop van enige eienaar-drywerstelsel beskou word. Verskeie ondernemings bied finansiële waarborge van finansiële instellings, maar die eienaar-drywer sal nadat hy eienaarskap van die vragmotor verkry het, op sy eie vermoë as sakeman aangewese moet wees.

Eienaar-drywers kan ook volle instandhoudingsbruikhuur oorweeg indien die huidige vragmotor nie meer koste-doelmatig funksioneer nie. Dit is veral van toepassing op vragmotors wat as gevolg van 'n hoë afstand- of tydsouderdom vervang moet word. Ondernemings wat tweedehandse vragmotors aan hulle vorige werknemers (eienaar-drywers) wil verkoop, moet veral hierop let. Eienaar-drywers het verskillende tipes voertuie, en die vergoedingsgrondslag van 'n eienaar-drywerstelsel moet hiervoor voorsiening maak.

Ondernemings moet probeer om hulle bedingingsmag tot voordeel van die eienaar-drywer aan te wend. Dit is ook van toepassing op bestuursmaatskappye en -agente wat namens die eienaar-drywers optree. Hulle kan, onder meer, betrokke raak by die bedinging van gunstige rentekoerse vir finansiering; billike versekeringspremies; keuse van die regte vragmotor en toerusting teen 'n markverwante rentekoers; omvattende onderhoudskontrakte; en korting op aankope van bande, brandstof en onderdele. 'n Eienaar-drywer behoort binne ' $n$ eienaar-drywerstelsel te deel in die voordele en besparing wat kollektief deur die koopkrag van die onderskeie eienaar-drywers verkry word, sonder om sy onafhanklike status as kontrakteur prys te gee. As onafhanklike kontrakteur moet hy hom steeds aan kontraktuele voorwaardes verbind.

Eienaar-drywers funksioneer wel as onafhanklike kontrakteurs, maar die meeste steun sterk op die hulp en leiding van die kontrakterende onderneming. Ondernemings het egter 'n verpligting ten opsigte van die opleiding en ontwikkeling van die eienaar-drywer as sakeman. Verantwoordelikheidsin kan ook gekweek word waar die bepaalde diensvlak-standaard gestel word, gedetailleerde state voorsien word, en rekordhouding verlang word. Eienaar-drywers behoort tydens die kontrakperiode tot een vragmotor per deelnemende drywer beperk te word. 'n Omvattende onderhoudskontrak is 'n belangrike element van 'n suksesvolle eienaar-drywerstelsel, alhoewel dit nie oral afdwingbaar is nie.

Eienaar-drywerstelsels bied oor die algemeen aansienlik meer voordele as nadele vir die betrokke partye. Eienaar-drywers werk meer gemotiveerd en verdien gemiddeld ook meer inkomste as wanneer hulle werknemers van die onderneming is. Die stelsel bied die ideale geleentheid vir die ontwikkeling van klein ondernemings.

\section{Implementering van 'n eienaar-drywerstelsel}

Die uitkontraktering van die onderneming se distribusiefunksie aan eienaar-drywers is ' $n$ proses wat sorgvuldig beplan en met toewyding bestuur moet word. Ondernemings moet be- reid wees om hulle te verbind tot die sukses van die stelsel op die lang termyn. Die werking van die eienaar-drywerstelsel moet deur al die betrokke partye verstaan word, en daar moet veral gewaak word teen die verkryging van korttermynvoordele wat slegs op tegniese of finansiële kriteria berus.

Everest (1997: 1) beklemtoon dit dat uitkontraktering nie 'n vinnige en eenvoudige oplossing vir die probleme van 'n onderneming is nie. Heelwat tyd en moeite word vereis om die voordele te maksimeer, en te verseker dat daar aan die kontrakvoorwaardes voldoen word. Dit is veral van toepassing waar daar moontlik verborge kostedrywers voorkom, en kommunikasie tussen die betrokke partye nie baie goed is nie. Verder kan die afwesigheid van voldoende data tot verkeerde besluite en duur oplossings lei.

Ondernemings moet dus die implementering van 'n eienaar-drywerstelsel op 'n gestrüktureerde wyse aanpak en besluitneming moet op gesonde sakebeginsels berus. Rothery \& Robertson (1995: 214-228) identifiseer ses fases waarvolgens die proses van uitkontraktering kan geskied, naamlik:

1. Aanvang;

2. Evaluering;

3. Beplanning;

4. Kontraktering;

5. Oorgang; en

6. Bestuur en hersiening.

Bogenoemde ses fases word vervolgens bespreek.

\section{Aanvangsfase}

Tydens hierdie fase word die omvang bepaal van wat presies alles uitgekontrakteer gaan word. Kriteria vir besluitneming word ontwikkel, asook watter mikpunte bereik moet word. Die tydsduur van hierdie fase kan van twee tot vier weke wissel. Dié fase word gewoonlik geïnisieer deur 'n senior bestuurder of direksielid, wat ook die latere uitvoerbaarheidsondersoek tydens die evalueringsfase ondersteun. 'n Dokument wat die omvang van die projek- en bestuurkwessies beskryf, behoort ook hieruit voort te spruit. Hierdie dokument moet veral die strategiese redes vir die uitkontraktering van 'n eienaar-drywerstelsel duidelik omskryf. Die vernaamste redes vir uitkontraktering is volgens Intercai (1997: 1) soos volg:

- Om koste te besnoei en/of te beheer;

- Om 'n beter diens aan kliënte te lewer; en

- Om te konsentreer op die onderneming se hoofaktiwiteit.

Verdere redes wat spesifiek van toepassing is op eienaardrywerstelsels, is:

- Om arbeidsprobleme uit te skakel;

- Om produktiwiteit te verbeter; en

- Om die werkerkorps te bemagtig.

Die meeste ondernemings beskou kostebesparing as die belangrikste beweegrede vir die uitkontraktering van 'n spesifieke funksie. Besparing word veral verkry waar die kontrakteur 'n goedkoper diens kan lewer as die onderneming. Personeelkoste kan besnoei word waar die kontrakteur sy eie personeel gebruik, en minder personeel dus intern benodig word. Uitkontraktering bring ook mee dat bates vanaf die balansstaat verwyder word, met die gepaardgaande groter kontantinvloei. Groter voorspelbaarheid van lopende uitgawes en kontantvloei lei regstreeks tot beter begrotingsbeheer. 
Braun (1997: 10) wys daarop dat ondernemings wat 'n eienaar-drywerstelsel wil implementeer, moet aanvaar dat die veranderihg in distribusiemetodes kompleks en moontlik duur sal wees. Ondernemings moet dus reeds by die aanvangsfase duidelikheid kry oor die redes waarom 'n eienaardrywerstelsel geïmplementeer behoort te word. Leenders (1997: 2) het bevind dat die uitkontraktering van die vlootbestuur soms as ' $n$ kitsoplossing gebruik word waar personeel verminder moet word, selfs in gevalle waar die besluit nie finansieel geregverdig is nie.

Die aanvangsfase behoort die volgende elemente in te sluit (Rothery \& Robertson, 1995: 219-220):

- Sorg vir die nodige verbintenis tot en toewyding aan die projek. Dit is ' $n$ belangrike stap wat veral die grondslag moet lê vir die daaropvolgende stappe. Gereelde kommunikasie met bestuur moet plaasvind.

- Kies 'n projekbestuurder. Die aard en omvang van die projek sal aantoon of die onderneming 'n kandidaat uit eie geledere gaan gebruik, of die dienste van 'n geskikte konsultant gaan bekom. Dit is belangrik dat die onderneming 'n bevoegde persoon aanstel wat as skakel tussen bestuur en die ander betrokke partye kan dien. Konsultante kan op verskeie wyses betrek word by die ontwikkeling en implementering van 'n eienaar-drywerstelsel. Hulle kan ook as bestuursagente betrokke raak om die stelsel te bestuur en te administreer.

- Bepaal tydskale. Die implementeringsproses moet volgens ' $n$ beplande tydskaal verloop. Die hoofaktiwiteit van dié proses moet geïdentifiseer en in verskillende fases met bepaalde tydgleuwe ingedeel word.

- Bepaal kriteria vir besluitneming en hoe die proses verder hanteer gaan word. Dit kan die opstel van 'n gedetailleerde plan vir die evalueringsfase, asook die identifisering en toewysing van die nodige bronne insluit.

\section{Evalueringsfase}

Ondersoek na die uitvoerbaarheid van die voorgenome uitkontraktering geskied tydens hierdie fase. Die omvang en grense van die projek word bepaal, en uitspraak word gelewer oor die bereikbaarheid van die projek se hoofdoelwit van bydrae tot groter langtermynwinsgewendheid, en die verskillende ondergeskikte mikpunte. Hierdie fase kan van vier tot ses weke duur met 'n uitvoerbaarheidsverslag as eindresultaat. Hiervolgens kan besluit word of met die projek voortgegaan kan word, al dan nie.

Die uitvoerbaarheidsondersoek behoort die volgende aspekte in te sluit (Rothery \& Robertson, 1995: 221-222):

1. Bepaling van basiese maatstawwe

Die vasstel van basiese maatstawwe sluit onder meer die bepaling van huidige diensvlakke en koste in. Al die verpligtinge van die funksie wat die onderneming wil uitkontrakteer, moet beskryf word. Sleutelprosesse waarby die distribusiefunksie betrokke is, behoort ook uiteengesit te word. Daardie maatstawwe wat die sukses, al dan nie, van die projek sal bepaal, moet gereed en klaar bereken wees om die stelsel te evalueer. Historiese koste is veral van belang vir die berekening van billike tariewe vir die eienaardrywers. Die verpligtinge van die onderneming se distribusiefunksie behoort die basis te vorm van die diensvlak- ooreenkoms tussen die onderneming en die eienaardrywer.

2. Bepaling van wat alles by die berekeningsproses ingesluit moet word

Dit sluit in die oordrag van bates; die hantering van die proses intern of, waar van toepassing, deur 'n derde party, die tipe diens wat deur kliënte vereis word; en die omvang van verwagte strategiese mededingingsvoordele wat verkry sal word.

3. Projekevaluering

Die projek moet evalueer word volgens verskillende alternatiewe vervoerscenario's wat by uitkontraktering mag ontstaan. Die volgende vrae kan tydens projekevaluering gevra word:

- Wat is die verskil tussen die huidige en die verlangde diensvlakke?

- Is daar ruimte vir interne verbeterings sonder om uit te kontrakteer?

- Wat sal die inteme (byvoorbeeld sakeveranderinge) en eksterne (byvoorbeeld wetgewing en markomstandighede) invloed van uitkontraktering in die toekoms op die onderneming wees?

Die moontlike impak van uitkontraktering op ander aspekte van die onderneming moet ook ontleed word.

4. Risiko-evaluering

Die vernaamste risiko's moet geïdentifiseer word. Hierdie risiko's moet beheer, en waar moontlik, tot die minimum beperk word. Daar moet bepaal word watter vlak van risiko met die kontrakteur (eienaar-drywer) gedeel sal word. Verder moet die invloed wat risiko's het op sekuriteit, vertroulike handelspraktyke, en koste vooraf bepaal word.

5. Uitvoerbaarheid van die projek

Die verwagte voordele van die projek moet vergelyk word met die geprojekteerde koste van die projek. Finansiële besluitneming oor uitkontraktering berus onder andere op hoe koste-doelmatig en diensdoeltreffend die ondememing is met die behartiging van sy eie vervoerfunksie.

Benewens die bepaling van finansiële lewensvatbaarheid van die projek, moet geoordeel word of dit versoenbaar en in harmonie is met die aard en omvang van die onderneming se bedrywighede. Die markomstandighede, hoe mededingers te werk gaan, en die langtermynstrategie van die onderneming moet oorweeg word. Ideaal-gesproke moet alle faktore van die projek wat 'n invloed op die onderneming sal hê, in ag geneem word.

\section{Beplanningsfase}

Die derde fase in die proses van uitkontraktering bestaan uit gedetailleerde beplanning wat betref diensvereistes, tenderof aansoekprosedures, asook die voorbereiding van die nodige dokumentasie. Agt tot tien weke kan toegelaat word vir hierdie fase. Die span wat betrokke was by die evalueringsfase kan ook die beplanning behartig. Regsverteenwoordigers asook verteenwoordigers van die menslike hulpbrondepartement kan belangrike insette lewer. Die eindproduk van hierdie fase sluit die volgende in:

- 'n Plan waarvolgens die aanstellingsproses (tender) sal verloop, wat ook die dokumentasie insluit; 
- Diensomskrywing van dit wat die onderneming wil uitkontrakteer; en

- 'n Strategie oor die wyse waarop samesprekings met potensiële kontrakteurs moet geskied. Die keuring van potensiële eienaar-drywers kan ook hieruit voortvloei.

Die beplanningsfase vereis dat die huidige distribusiestelsel in ooreenstemming gebring word met die werking van die beoogde eienaar-drywerstelsel. Die volgende aantal punte, soos gelys deur Rypstra (1995: 11-12) is veral van belang in hierdie fase:

- Die spesifikasie van die voertuig en aanboord/kajuittoerusting;

- Bedryfsprosedures;

- Organisatoriese reëlings;

- Administratiewe prosedures;

- Die onderhandeling- en seleksieproses (menslike hulpbronneprosedures);

- Opleidingspesifikasies;

- Eienaar-drywerkontrakte;

- Finansiële bronne; en

- Onderhoudspesifikasie.

\section{Kontraktering}

Kontraktering van eienaar-drywers en die oorgangsfase is baie nou verwant aan mekaar. Tydens kontraktering kan kundiges van buite die onderneming (regsadviseurs, arbeids- en vervoerkonsultante) met groot vrug gebruik word. Die periode kan drie tot vier maande duur waarin die kontrak en die diensvlakooreenkoms of bedryfshandleiding gefinaliseer word. Daar kan hiertydens begin word om die oorgangsfase te beplan. Die kontrakperiode en -voorwaardes word ook in hierdie fase bepaal.

Dit is gewens dat ' $n$ loodsprojek in hierdie fase moet geskied. Potensiële eienaar-drywers kry tydens so 'n oefenlopie of 'kleedrepetisie' die geleentheid om hulle nuwe verantwoordelikhede, asook die werking van die eienaar-drywerstelsel te leer ken. Die onderneming kan weer op sy beurt die nodige aanpassings en wysigings maak wat betref die diensvlakooreenkoms (bedryfshandleiding), asook sekere aspekte van die kontrak voordat kontraktering finaal geskied. Potensiële eienaar-drywers kan in hierdie fase as skynkontrakteurdrywers behandel word sodat hulle 'n beter begrip van al die inkomste en uitgawes kan kry nog voordat die risiko van eienaarskap van die vragmotor en die bedryfsverpligtinge werklik deur hulle aanvaar word.

Die uitkontraktering van 'n onderneming se vervoerverpligtinge aan individue, hoef nie noodwendig gepaard te gaan met die verkoop van die onderneming se vragmotors nie. Deur slegs die bestuursfunksie van die vragmotor aan die betrokke individu uit te kontrakteer, behou die onderneming eienaarskap en beheer oor die vragmotors. Die drywer besit dus geen eienaarskap oor die vragmotors nie, maar tree wel op as 'n onafhanklike kontrakteur.

Hierdie tipe stelsel kan beskryf word as 'n kontrakteur-drywerstelsel. Daar bestaan wel ooreenkomste tussen dié stelsel en die eienaar-drywerstelsel. In beide stelsels word drywerinkomste gekoppel aan dienste gelewer. Dienste word op 'n kontrakbasis gelewer, en drywers kan met die nodige toestemming hulle dienste ook aan ander beskikbaar stel. Die implementering van 'n kontrakteur-drywerstelsel kan, soos die voorgestelde loodsprojek hierbo, ook as 'n oorbruggingsfase gebruik word, voordat 'n eienaar-drywerstelsel geïmplementeer word. Beide die onderneming en die kontrakteur kan hierdeur waardevolle ondervinding opdoen vir die bestuur en bedryf van 'n eienaar-drywerstelsel.

Rypstra (1995: 11) is van mening dat die onderneming se uitvoerende bestuur deur middel van die bedryfskontrak kan bydra tot die ekonomiese bemagtiging van drywers deur in hierdie kontrak voorsiening te maak vir die volgende:

- 'n Gewaarborgde minimum paaiement wat voldoende is om al die vaste koste van die gefinansierde toerusting (hoofsaaklik die vragmotor) te dek;

- Die instel van termynkontrakte van drie jaar of langer;

- Die ondersteuning van die administratiewe prosedures wat vereis word vir beheer wan die eienaar-drywerstelsel; en

- Die verskaffing van die nodige fasiliteite en voortgesette opleiding van eienaar-drywers.

Die diensvlakooreenkoms (bedryfshandleiding) is 'n belangrike verlengingstuk van die kontrak. Hierdie ooreenkoms gee duidelike riglyne aan die eienaar-drywer van wat van hom as kontrakteur verwag word. Intercai (1973: 3-4) beveel aan dat enige diensvlakooreenkoms die volgende aspekte behoort in te sluit:

- 'n Prysbeheermeganisme sodat beide partye bewus sal wees van prysvlakke wat moontlik in die toekoms van toepassing mag wees;

- Vergelykbare maatstawwe ('benchmarks') waarvolgens dienslewering voortdurend teenoor nastreefbare maar tog bereikbare standaarde opgeweeg kan word; en

- 'n Opskortingsmeganisme wat die kontrak sal beëindig as daar nie aan die verwagtinge van uitkontraktering voldoen word nie.

\section{Oorgangsfase}

Die oorgangsfase is ' $n$ kritieke fase in die uitkontrakteringsproses. Die oordrag van diensverpligtinge na die eienaar-drywer vind nou plaas. Voorsorg moet getref word dat kliënte van die onderneming nie tydens hierdie fase verwaarloos word nie. Inligting vooraf en gereelde kommunikasie is belangrik om alle betrokke partye wat deur die oorgangsfase geraak word, op die hoogte van veranderende distribusiewyse en ander verwikkelinge te hou. Hierdie fase kan twee tot drie maande duur, maar dit is belangrik dat dit nie oorhaastig afgehandel word nie.

Heelwat dokumentasie moet afgehandel word met die oordrag van personeel, bates, en diensverpligtinge, wat verskeie vorme kan aanneem. Opleiding moet aan personeel én eienaar-drywers verskaf word sodat almal hulle verpligtinge behoorlik kan nakom en dienskontinuïteit gehandhaaf word. Die aard van 'n eienaar-drywer se onderneming kan verskeie vorme aanneem, waaronder alleeneienaarskap, vennootskap, beslote korporasie, private maatskappy, of trust die waarskynlikste vorme is. Voordat die eienaar-drywer sy onderneming mag bedryf, moet die eienaar-drywer dit na gelang van omstandighede by sekere owerheidsinstansies registreer vir:

- Voorlopige belasting;

- Werknemersbelasting (LBS) en standaard inkomstebelasting op werknemers (SIBW);

- Belasting op toegevoegde waarde (BTW); 
- Werkloosheidsversekering; en

- Streeksdiensteraadheffing.

\section{Bestuur en hersieningsfase}

Die laaste fase in die uitkontrakteringsproses is dié van bestuur en hersiening van die stelsel. Hersiening van die kontrak behoort op ' $n$ gereelde basis te geskied met die ooreengekome diensvlakke as kriteria. Onderhandelinge is nodig om voorsiening te maak vir veranderinge of waar bykomende vereistes gestel word. Uit die ondersoek na eienaar-drywerstelsels is dit duidelik dat veral tariewe op 'n jaarlikse grondslag bespreek moet word. Verder is dit belangrik dat gereelde ontmoetings tussen die betrokke partye moet plaasvind. Hiertydens behoort eienaar-drywers deur 'n eienaar-drywerkomitee verteenwoordig te word. Eienaar-drywers moet steeds as individuele onafhanklike kontrakteurs hanteer word, maar daar is verskeie sake wat van gemeenskaplike belang is.

Die kontrakperiode wissel gewoonlik vanaf een tot vyf jaar volgens die onderneming se behoeftes. Dit is wenslik dat die kontrakperiode ten minste so lank soos die termyn van die finansieringskontrak moet wees. Dit beteken dat die eienaardrywer verseker moet wees van 'n dienskontrak vir die periode waartydens hy sy lening delg. Finansiële instellings vereis normaalweg dat daar 'n klousule vir minimum loonvrag (wat naastenby vir 'n maandelikse finansiële gelykbreekpunt voorsiening makk) in die kontrak is, of dat die onderneming vir die finansiering van die vragmotor borg staan.

Die implementering van 'n eienaar-drywerstelsel moet oor die lang termyn beskou word, en die proses moet hiervolgens bestuur word. Dit is belangrik dat die eienaar-drywer die nodige ondersteuning en hulp vanaf die onderneming en die bestuursmaatskappy moet verkry. Die kontrakperiode behoort om hierdie rede in twee verdere fases (Fase I en Fase II) verdeel te word.

Tydens Fase I, wat kan wissel van een tot twee jaar, beskik die eienaar-drywer nog nie oor eienaarskap van die vragmotor nie. Hy is egter verantwoordelik vir alle koste, behalwe vir die betaling van die maandelikse paaiement van die vragmotor. Dit gee aan die onderneming of die bestuursmaatskappy 'n goeie aanduiding of die eienaar-drywer kan voldoen aan al die vereistes, en van die billikheid van dịe kontrak. Die finansiële risiko is ook aansienlik minder vir die eienaar-drywer. Na Fase I kan al die betrokke partye besin oor die wenslikheid vir die implementering van Fase II.

Fase II breek aan wanneer die eienaar-drywer verantwoordelikheid aanvaar vir die maandelikse afbetalingspaaiement. Hierdie fase kan wissel van drie tot vyf jaar. Na afloop van hierdie periode behoort die eienaar-drywer as volwaardige en ontvoogde sakepersoon sonder enige bystand van die onderneming of bestuursmaatskappy te kan funksioneer. Hy kan dan as 'n ongebonde entrepreneur optree, wat nuwe markte en geleenthede kan ontwikkel. Die uitbreiding van sy aantal vragmotors is ook hierby ingesluit.

Eienaarskap oor die vragmotor behoort ná Fase II aan die eienaar-drywer oorgedra te word. Daar kan dus na die kontrakperiode 'n klemverskuiwing vanaf eienaar-drywer na eienaar-operateur intree. Laasgenoemde dui wel op eienaarskap van die vragmotor, maar die eienaar en drywer hoef nie noodwendig kontraktueel dieselfde persoon te wees nie. Die eienaar-drywer word dus 'n karweier wat met ander vir die verkryging van kontrakte meeding.

Dit is belangrik dat die funksionering van die eienaar-drywerstelsel gereeld hersien moet word. Die ooreengekome maatstawwe is baie belangrik, want dit bepaal die vergoeding en ook die nodige boetes, waar van toepassing, volgens die betrokke partye se prestasie en dienslewering. Enige verandering of afwyking moet binne die omvang van die kontrak bestuur word.

Weens gebrekkige beheer word vele eienaar-drywerstelsels nie kostedoelmatig en/of diensdoeltreffend bedryf nie. Die gehalte van die diens aan kliënte van die onderneming behoort gereeld ondersoek te word. 'n Onafhanklike oudit van die diensgehalte (wat die prestasies insluit) en tevredenheid van kliënte behoort gereeld gedoen te word. Die geldigheid van die oorspronklike uitvoerbaarheidsondersoek (wat in die evalueringsfase uitgevoer is) behoort ook in oënskou geneem te word. Hiervolgens kan die volgende verskillende altematiewe teen mekaar opgeweeg word:

- Keer terug na oorspronklike situasie deur die vervoer weer intern as hulpfunksie te hanteer;

- Verander van kontrakteurs (eienaar-drywers);

- Verander die omvang van dit wat uitgekontrakteer moet word en/of hersien die vereistes en maatstawwe wat met uitkontraktering gepaard gaan; en

- Onderhandel weer oor voortsetting van die kontrak.

Hersiening behoort aanvanklik deurlopend plaas te vind, maar namate aanpassing en die leerproses afplat, behoort een deeglike hersieningsessie per maand later voldoende te wees.

\section{Gevolgtrekkings}

Die hoofdoelwit van 'n eienaar-drywerstelsel is om deur middel van produktiwiteitsverbetering die langtermynwinsgewendheid van die onderneming te verhoog. Die groter produktiwiteit kan enersyds deur besparings en andersyds deur hoër opbrengs op kapitaal bewerkstellig word. Die besparings word teweeggebring deur die vervoerfunksie teen laer koste te laat plaasvind. Die verhoging van kapitaalopbrengs word bewerkstellig deurdat die onderneming beter in staat is om op sy primêre sake-aktiwiteite te fokus, en omdat eienaar-drywers dit lonend vind om 'n goeie gehalte en doeltreffende diens teen 'n hoë werkverrigtingsvlak aan kliënte te lewer.

Die implementering van ' $n$ eienaar-drywerstelsel vereis dal 'n langtermynbenadering gevolg word. Dit is raadsaam om eers te begin met 'n loodsprojek waar net 'n paar eienaar-drywers op 'n proefbasis tydens 'n oefenlopie aangestel word. ' Loodsprojek is veral belangrik vir die identifisering van potensiële probleme, en om te help bepaal of 'n eienaar-drywerstelsel finansieel en andersins geregverdig sal wees vir al die betrokke partye. Verder kan 'n loodsprojek bydra daartoe dal 'n billike en omvattende kontrak ontwikkel word.

Bevoegde bestuursmaatskappye of vervoerkonsultante kan 'n wesenlike bydrae lewer tot die ontwikkeling en implementering van 'n eienaar-drywerstelsel. Hulle kundigheid en ondervinding kan daartoe lei dat baie koste en tyd vir die onderneming bespaar word. As derde party kan hulle ook groter deursigtigheid en ewewigtigheid aan die eienaar-drywerstelsel verleen, deurdat daar ook na die belange van die eienaardrywer gekyk word. 
Drywerseleksie is van groot belang, en kan uitgesonder word as een van die belangrikste faktore wat die sukses van 'n eienaar-drywerstelsel bepaal. Keuring en toetsing moet op 'n gestruktureerde wyse geskied, en verkieslik deur 'n onafhanklike party gedoen word. Eienaar-drywers moet die potensiaal toon dat hulle die nuwe verantwoordelikhede om as 'n onafhanklike kontrakteur op te tree, sal kan hanteer. Nie alle drywers kan eienaar-drywers word nie.

Dit is raadsaam om die werknemers se vakbonde deurgaans te raadpleeg in die implementering van 'n eienaar-drywerstelsel. Die wyse van raadpleging sal na gelang van die kultuur en vlak van arbeidsverhoudinge tussen ondernemings verskil.

Ondernemings moet probeer om hulle bedingingsmag tot voordeel van die eienaar-drywer aan te wend. Dit is ook van toepassing op bestuursmaatskappye en -agente wat namens die eienaar-drywers optree. Hulle kan, onder meer, betrokke raak by die bedinging van gunstige rentekoerse vir finansiering; billike versekeringspremies; keuse van die regte vragmotor en toerusting teen 'n markverwante rentekoers; omvattende onderhoudskontrakte; en korting op aankope van bande, brandstof en onderdele. 'n Eienaar-drywer behoort binne 'n eienaar-drywerstelsel te deel in die voordele en besparing wat kollektief deur die koopkrag van die onderskeie eienaar-drywers verkry word, sonder om sy onafhanklike status as kontrakteur prys te gee. As onafhanklike kontrakteur moet hy hom steeds aan kontraktuele voorwaardes verbind.

Voortdurende opleiding en ontwikkeling van die eienaardrywer om sy volle potensiaal as 'n onafhanklike kontrakteur en sakeman te bereik, is noodsaaklik. Daar behoort 'n gestruktureerde opleidingsprogram te wees wat kan help deur advies en leiding te gee met algemene boekhouding, basiese ondernemingsbestuur, wetgewing en die opstel van sakeplanne. Die standaarde en vereistes wat in die diensvlak-ooreenkoms gestel word, kan deur middel van opleiding in groter perspektief geplaas word. Dit bied 'n platform van waar insette en terugvoering aan al die betrokke partye kan geskied.

Eienaar-drywers moet verseker wees van genoeg vrag en billike tariewe, sodat al die partye by die stelsel kan baat. Die vergoedingstelsel moet voorsiening maak vir al die relevante koste, en as aansporing vir die eienaar-drywer dien om 'n koste-doelmatige en doeltreffende diens te lewer.

\section{Summary}

The implementation of an owner-driver scheme is the outsourcing of a firm's transport activities to vehicle ownerdrivers who are not employees of the firm. In most cases these individuals are ex-employees of the firm who are now acting as independent hauliers.

The primary goal of an owner-driver scheme is to enhance a firm's long-run profitability through productivity improvement. Greater productivity can be achieved through cost savings and increased returns. Cost savings are achieved by conducting the transport function more efficiently. Increases in returns may result from the fact that the firm now has the opportunity to fully concentrate on its primary business functions, and because owner-drivers are being rewarded for greater output and for more effectively conforming to customer service requirements. Secondary objectives of an owner-driver scheme can be to reduce labour problems and to empower the work force.
An owner-driver scheme can adopt various forms, each one tailored to meet the needs of the firm. Implementation of the various forms of an owner-driver scheme can be implemented in one of three ways: (1) the development of an own scheme. (2) the establishment of an independent scheme, and (3) the formation of a scheme which is managed by an autonomous management firm.

The following criteria, which are prerequisites for successful implementation, should be adhered to:

- clear objectives and strategies for success attainment must be identified;

- the scheme must be run on business principles;

- the selection process should be comprehensive to ensure that the most suitable persons are chosen to become owner-drivers;

- the implementation process should include thorough training;

- owner-drivers should be remunerated on an incentive basis;

- the scheme should be mutually beneficial for the firm and the owner-driver;

- the scheme should be run in a transparent manner with an open-door communication policy; and

- the firm should maintain a supportive role and guide the owner-drivers towards high quality performance.

The above-mentioned success criteria rest on four imperatives, namely:

- conduct a pilot project to serve as a 'dress rehearsal';

- extension or growth of the scheme should take place at a controlled pace;

- the owner-driver selection mechanism should be sound and desirable driver characteristics must not be compromised as the scheme progresses; and

- the remuneration, and supplementary incentive reward system should take cognisance of market fluctuations so that owner-drivers can make ends meet during slumps.

The implementation of an owner-driver scheme should be well structured and managed, incorporating the following six phases: (1) initiation, (2) evaluation, (3) planning, (4) contracting, (5) transition, and (6) management and review.

The initiation should include the following elements: (1) establish commitment towards the scheme, (2) appoint a project manager, (3) determine timescales for implementation, and (4) determine decision-making criteria.

The evaluation should cover at least an assessment of (1) the service requirements, (2) any risk involved, and (3) the financial feasibility.

Planning should cover (1) vehicle and equipment specification, (2) operational procedures, (3) organisational strategies, (4) administrative procedures, (5) driver selection, (6) training, (7) contract preparation, (8) financial arrangements and (9) maintenance specification

The contract should cover (1) the terms of remuneration, (2) the level of service to be provided, and (3) cancellation clauses.

During the transitionary phase the ownership of the vehicles and responsibility of execution of the distribution function are transferred to the newly appointed drivers. 
- Werkloosheidsversekering; en

- Streeksdiensteraadheffing.

\section{Bestuur en hersieningsfase}

Die laaste fase in die uitkontrakteringsproses is dié van bestuur en hersiening van die stelsel. Hersiening van die kontrak behoort op 'n gereelde basis te geskied met die ooreengekome diensvlakke as kriteria. Onderhandelinge is nodig om voorsiening te maak vir veranderinge of waar bykomende vereistes gestel word. Uit die ondersoek na eienaar-drywerstelsels is dit duidelik dat veral tariewe op 'n jaarlikse grondslag bespreek moet word. Verder is dit belangrik dat gereelde ontmoetings tussen die betrokke partye moet plaasvind. Hiertydens behoort eienaar-drywers deur 'n eienaar-drywerkomitee verteenwoordig te word. Eienaar-drywers moet steeds as individuele onafhanklike kontrakteurs hanteer word, maar daar is verskeie sake wat van gemeenskaplike belang is.

Die kontrakperiode wissel gewoonlik vanaf een tot vyf jaar volgens die onderneming se behoeftes. Dit is wenslik dat die kontrakperiode ten minste so lank soos die termyn van die finansieringskontrak moet wees. Dit beteken dat die eienaardrywer verseker moet wees van 'n dienskontrak vir die periode waartydens hy sy lening delg. Finansiële instellings vereis normaalweg dat daar 'n klousule vir minimum loonvrag (wat naastenby vir 'n maandelikse finansiële gelykbreekpunt voorsiening maak) in die kontrak is, of dat die onderneming vir die finansiering van die vragmotor borg staan.

Die implementering van 'n eienaar-drywerstelsel moet oor die lang termyn beskou word, en die proses moet hiervolgens bestuur word. Dit is belangrik dat die eienaar-drywer die nodige ondersteuning en hulp vanaf die onderneming en die bestuursmaatskappy moet verkry. Die kontrakperiode behoort om hierdie rede in twee verdere fases (Fase I en Fase II) verdeel te word.

Tydens Fase I, wat kan wissel van een tot twee jaar, beskik die eienaar-drywer nog nie oor eienaarskap van die vragmotor nie. Hy is egter verantwoordelik vir alle koste, behalwe vir die betaling van die maandelikse paaiement van die vragmotor. Dit gee aan die onderneming of die bestuursmaatskappy 'n goeie aanduiding of die eienaar-drywer kan voldoen aan al die vereistes, en van die billikheid van die kontrak. Die finansiële risiko is ook aansienlik minder vir die eienaar-drywer. $\mathrm{Na}$ Fase I kan al die betrokke partye besin oor die wenslikheid vir die implementering van Fase II.

Fase II breek aan wanneer die eienaar-drywer verantwoordelikheid aanvaar vir die maandelikse afbetalingspaaiement. Hierdie fase kan wissel van drie tot vyf jaar. Na afloop van hierdie periode behoort die eienaar-drywer as volwaardige en ontvoogde sakepersoon sonder enige bystand van die onderneming of bestuursmaatskappy te kan funksioneer. Hy kan dan as 'n ongebonde entrepreneur optree, wat nuwe markte en geleenthede kan ontwikkel. Die uitbreiding van sy aantal vragmotors is ook hierby ingesluit.

Eienaarskap oor die vragmotor behoort ná Fase II aan die eienaar-drywer oorgedra te word. Daar kan dus na die kontrakperiode 'n klemverskuiwing vanaf eienaar-drywer na eienaar-operateur intree. Laasgenoemde dui wel op eienaarskap van die vragmotor, maar die eienaar en drywer hoef nie noodwendig kontraktueel dieselfde persoon te wees nie. Die eienaar-drywer word dus 'n karweier wat met ander vir die verkryging van kontrakte meeding.

Dit is belangrik dat die funksionering van die eienaar-drywerstelsel gereeld hersien moet word. Die ooreengekome maatstawwe is baie belangrik, want dit bepaal die vergoeding en ook die nodige boetes, waar van toepassing, volgens die betrokke partye se prestasie en dienslewering. Enige verandering of afwyking moet binne die omvang van die kontrak bestuur word.

Weens gebrekkige beheer word vele eienaar-drywerstelsels nie kostedoelmatig en/of diensdoeltreffend bedryf nie. Die gehalte van die diens aan kliënte van die onderneming behoort gereeld ondersoek te word. 'n Onafhanklike oudit van die diensgehalte (wat die prestasies insluit) en tevredenheid van kliënte behoort gereeld gedoen te word. Die geldigheid van die oorspronklike uitvoerbaarheidsondersoek (wat in die evalueringsfase uitgevoer is) behoort ook in oënskou geneem te word. Hiervolgens kan die volgende verskillende altematiewe teen mekaar opgeweeg word:

- Keer terug na oorspronklike situasie deur die vervoer weer intern as hulpfunksie te hanteer;

- Verander van kontrakteurs (eienaar-drywers);

- Verander die omvang van dit wat uitgekontrakteer moet word en/of hersien die vereistes en maatstawwe wat met uitkontraktering gepaard gaan; en

- Onderhandel weer oor voortsetting van die kontrak.

Hersiening behoort aanvanklik deurlopend plaas te vind, maar namate aanpassing en die leerproses afplat, behoort een deeglike hersieningsessie per maand later voldoende te wees.

\section{Gevolgtrekkings}

Die hoofdoelwit van 'n eienaar-drywerstelsel is om deur middel van produktiwiteitsverbetering die langtermynwinsgewendheid van die onderneming te verhoog. Die groter produktiwiteit kan enersyds deur besparings en andersyds deur hoër opbrengs op kapitaal bewerkstellig word. Die besparings word teweeggebring deur die vervoerfunksie teen laer koste te laat plaasvind. Die verhoging van kapitaalopbrengs word bewerkstellig deurdat die onderneming beter in staat is om op sy primêre sake-aktiwiteite te fokus, en omdat eienaar-drywers dit lonend vind om 'n goeie gehalte en doeltreffende diens teen 'n hoè werkverrigtingsvlak aan kliënte te lewer.

Die implementering van ' $n$ eienaar-drywerstelsel vereis dat 'n langtermynbenadering gevolg word. Dit is raadsaam om eers te begin met ' $n$ loodsprojek waar net 'n paar eienaar-drywers op 'n proefbasis tydens 'n oefenlopie aangestel word. 'n Loodsprojek is veral belangrik vir die identifisering van potensiële probleme, en om te help bepaal of 'n eienaar-drywerstelsel finansieel en andersins geregverdig sal wees vir al die betrokke partye. Verder kan 'n loodsprojek bydra daartoe dat 'n billike en omvattende kontrak ontwikkel word.

Bevoegde bestuursmaatskappye of vervoerkonsultante kan 'n wesenlike bydrae lewer tot die ontwikkeling en implementering van 'n eienaar-drywerstelsel. Hulle kundigheid en ondervinding kan daartoe lei dat baie koste en tyd vir die onderneming bespaar word. As derde party kan hulle ook groter deursigtigheid en ewewigtigheid aan die eienaar-drywerstelsel verleen, deurdat daar ook na die belange van die eienaardrywer gekyk word. 
Drywerseleksie is van groot belang, en kan uitgesonder word as een van die belangrikste faktore wat die sukses van 'n eienaar-drywerstelsel bepaal. Keuring en toetsing moet op 'n gestruktureerde wyse geskied, en verkieslik deur 'n onafhanklike party gedoen word. Eienaar-drywers moet die potensiaal toon dat hulle die nuwe verantwoordelikhede om as 'n onafhanklike kontrakteur op te tree, sal kan hanteer. Nie alle drywers kan eienaar-drywers word nie.

Dit is raadsaam om die werknemers se vakbonde deurgaans te raadpleeg in die implementering van ' $n$ eienaar-drywerstelsel. Die wyse van raadpleging sal na gelang van die kultuur en vlak van arbeidsverhoudinge tussen ondernemings verskil.

Ondernemings moet probeer om hulle bedingingsmag tot voordeel van die eienaar-drywer aan te wend. Dit is ook van toepassing op bestuursmaatskappye en -agente wat namens die eienaar-drywers optree. Hulle kan, onder meer, betrokke raak by die bedinging van gunstige rentekoerse vir finansiering; billike versekeringspremies; keuse van die regte vragmotor en toerusting teen 'n markverwante rentekoers; omvattende onderhoudskontrakte; en korting op aankope van bande, brandstof en onderdele. 'n Eienaar-drywer behoort binne ' $n$ eienaar-drywerstelsel te deel in die voordele en besparing wat kollektief deur die koopkrag van die onderskeie eienaar-drywers verkry word, sonder om sy onafhanklike status as kontrakteur prys te gee. As onafhanklike kontrakteur moet hy hom steeds aan kontraktuele voorwaardes verbind.

Voortdurende opleiding en ontwikkeling van die eienaardrywer om sy volle potensiaal as 'n onafhanklike kontrakteur en sakeman te bereik, is noodsaaklik. Daar behoort 'n gestruktureerde opleidingsprogram te wees wat kan help deur advies en leiding te gee met algemene boekhouding, basiese ondernemingsbestuur, wetgewing en die opstel van sakeplanne. Die standaarde en vereistes wat in die diensvlak-ooreenkoms gestel word, kan deur middel van opleiding in groter perspektief geplaas word. Dit bied 'n platform van waar insette en terugvoering aan al die betrokke partye kan geskied.

Eienaar-drywers moet verseker wees van genoeg vrag en billike tariewe, sodat al die partye by die stelsel kan baat. Die vergoedingstelsel moet voorsiening maak vir al die relevante koste, en as aansporing vir die eienaar-drywer dien om 'n koste-doelmatige en doeltreffende diens te lewer.

\section{Summary}

The implementation of an owner-driver scheme is the outsourcing of a firm's transport activities to vehicle ownerdrivers who are not employees of the firm. In most cases these individuals are ex-employees of the firm who are now acting as independent hauliers.

The primary goal of an owner-driver scheme is to enhance a firm's long-run profitability through productivity improvement. Greater productivity can be achieved through cost savings and increased returns. Cost savings are achieved by conducting the transport function more efficiently. Increases in returns may result from the fact that the firm now has the opportunity to fully concentrate on its primary business functions, and because owner-drivers are being rewarded for greater output and for more effectively conforming to customer service requirements. Secondary objectives of an owner-driver scheme can be to reduce labour problems and to empower the work force.
An owner-driver scheme can adopt various forms, each one tailored to meet the needs of the firm. Implementation of the various forms of an owner-driver scheme can be implemented in one of three ways: (1) the development of an own scheme, (2) the establishment of an independent scheme, and (3) the formation of a scheme which is managed by an autonomous management firm.

The following criteria, which are prerequisites for successful implementation, should be adhered to:

- clear objectives and strategies for success attainment must be identified;

- the scheme must be run on business principles;

- the selection process should be comprehensive to ensure that the most suitable persons are chosen to become owner-drivers;

- the implementation process should include thorough training;

- owner-drivers should be remunerated on an incentive basis;

- the scheme should be mutually beneficial for the firm and the owner-driver;

- the scheme should be run in a transparent manner with an open-door communication policy; and

- the firm should maintain a supportive role and guide the owner-drivers towards high quality performance.

The above-mentioned success criteria rest on four imperatives, namely:

- conduct a pilot project to serve as a 'dress rehearsal';

- extension or growth of the scheme should take place at a controlled pace;

- the owner-driver selection mechanism should be sound and desirable driver characteristics must not be compromised as the scheme progresses; and

- the remuneration, and supplementary incentive reward system should take cognisance of market fluctuations so that owner-drivers can make ends meet during slumps.

The implementation of an owner-driver scheme should be well structured and managed, incorporating the following six phases: (1) initiation, (2) evaluation, (3) planning, (4) contracting, (5) transition, and (6) management and review.

The initiation should include the following clements: (1) establish commitment towards the scheme, (2) appoint a project manager, (3) determine timescales for implementation, and (4) determine decision-making criteria.

The evaluation should cover at least an assessment of (1) the service requirements, (2) any risk involved, and (3) the financial feasibility.

Planning should cover (1) vehicle and equipment specification, (2) operational procedures, (3) organisational strategies, (4) administrative procedures, (5) driver selection, (6) training, (7) contract preparation, (8) financial arrangements and (9) maintenance specification.

The contract should cover (1) the terms of remuneration, (2) the level of service to be provided, and (3) cancellation clauses.

During the transitionary phase the ownership of the vehicles and responsibility of execution of the distribution function are transferred to the newly appointed drivers. 
During the review phase the operational and service performance of the drivers are monitored. The success of the scheme is reviewed against the stated goals and objectives, and remedial action should be taken if significant operational and service deviations occur.

\section{Bronnelys}

Braun, M. 1997. Response to owner/driver allegations, Fleetwatch. Julie: $9-10$

Chapman. C. 1995. A win-win partnership, Enterprise, Desember: 60

Donohue. K. 1991. Owner drivers and the dependency relationship in the road freight transport, International Journal of Transport Economics. 18(1): 55-77.

Everest, J. 1997. How to avoid a multi-million dollar mistake, Building a good relationship with your outsourcer: Introduction. [Intyds] Beskikbaar: http://www.outsourcing mgmt. com/mistake/ intro.html 30 Julie
Intercai, J. 1997. Outsourcing. [Intyds] Beskikbaar: http:// www.intercai.com/reports/ outsour.htm $30 \mathrm{Julie}$

Leenders, M. 1997. Fleet management outsourcing - a viable option? [Intyds] Beskikbaar: http://www.ivey.uwo.co/ publications/impact/vol2 12 .htm 19 Julie

Nissan Diesel. 1996. Trucking Insight No. 2. Owner-drivers in perspective.

Prodrive (Pty) Ltd. 1997. Owner-driver scheme. Constantia Kloof. (Inligtingstuk.)

Robbertse, J.F. 1991. Developing a physical distribution strategy for Appletiser pure fruit juice products in the Port Elizabeth area. MBA-werkstuk. Stellenbosch: Universiteit van Stellenbosch.

Rothery, B. \& Robertson, I. 1995. The truth about outsourcing. Hampshire: Gower.

Rypstra, U. 1995. The win-win contract. Transport Management, Februarie: 11-13

Rypstra, U. 1996. Owners in the driver"s seat. Transport Management, Februarie: 33-38.

Suid-Afrika. Die Nasionale Padverkeerwet, No. 93 van 1996. 